ге Колумбия (1) и Северной Каролине (1), а туристические объекты, связанные с Гражданской войной, расположены в восьми итатах, причем три из них - в штате Пенсильвания, и по одному - в Федеральном округе Колумбия, Южной Каролине, Теннесси, Мэриленде и Миссисипи. Всего насчитывается 14 памятников, относящихся к периодам Войны за независимость и Гражданской войне, они расположены в девяти штатах с наибольшим количеством памятников, сосредоточенных в штате Пенсильвания (3, все связаны с Гражданской войной), Федеральном округе Колумбия (2), Вирджинии (2 - связаны с Войной за независимость). Из всех 14 памятников шесть относятся к Войне за независимость, а восемь - кГражданской войне США.

Ключевые слова: военный туризм, ресурсная база, США, Война за независимость, Гражданская война, география.

I. Smyrnov, Doctor of Science in Geography, Professor, V. Burnis, Student

Taras Shevchenko National University of Kyiv, Kyiv, Ukraine

\title{
GEOGRAPHY OF MILITARY TOURISM RESOURCE BASE IN USA (XVIII-XIX CENT.)
}

The peculiarities of the resource base of military tourism on the example of the USA are considered, in particular, military-historical tourist objects connected with the American War for Independence and the Civil War. The division of military tourism into such subspecies as militaryhistorical, armored, military -tourism, military-historical festivals and reconstructions has been described. The list of countries of the world - the leaders on the number of tourist arrivals and the volume of tourism revenues and the place of the USA in this register are given. The features of the US military-historical tourist objects associated with the War of Independence (1775-1783) are revealed, in particular: the Washington Monument, the mansion of the first US president "Mount Vernon", the Yorktown Battle Museum and the Victory Center, the National Military Historical Park "Saratoga", National Military History Park "Gilfort Courthouse", US Military Academy "West Point". Connected with the Civil War in the United States (1861-1865 are military-historical tourist sites such as: the Lincoln Memorial, the National Museum of the Civil War of the United States, the National Monument "Fort Sumter", the National Military Park "Shailo", the Museum Battle of Antitam, Vicksberg National Military Park, Petersberg Museum of Fight, Gettisberg National Historical Park. The geographic features of the US military tourism resource base in the seventeenth and nineteenth centuries have been analyzed. The results of the analysis are summarized in the table, from which it is evident that objects of the resource base of tourism related to the War of Independence are concentrated in four US states, namely, Virginia (2), New York (2), the Federal District of Columbia (1) and North Carolina (1), and tourist sites related to the Civil War are located mainly in eight states, with three of them - in the state of Pennsylvania and one - in the Federal District of Columbia, one - in South Carolina, one - in Tennessee, one - in Maryland, one - in Mississippi. All together there are 14 monuments belonging to the War of Independence and the Civil War, and they are located in 9 states, with the largest monuments concentrated in the state of Pennsylvania (3, all related to the Civil War), the Federal District of Columbia ( 2), Virginia (2 associated with the War of Independence). Of the all 14 monuments, six relate to the War of Independence, and eight - to the Civil War.

Key words: military tourism, resource base, USA, War for Independence, Civil War, geography.

http://doi.org/10.17721/1728-2721.2017.68.27

УДК 911.3:32/477

В. Стафрійчук, канд. геогр. наук, доц.
Київський національний університет імені Тараса Шевченка, Київ

\section{СУЧАСНЕ РЕГІОНАЛЬНЕ ПОЛІТИКО-ГЕОГРАФІЧНЕ ПОЛОЖЕННЯ УКРАЇНИ}

Розглянуто сучасне регіональне політико-географічне положення України як центральноєвропейської держави. На основі бальної оцінки иентральноєвропейські держави об'єднані в групи за пріоритетністю співпраці для України. Висвітлено основні проблеми і напрями двох- та багатостороннього співробітництва Украӥни з найважливішими з них, а саме Польщею, Литвою, Чехією, Румунією. Проаналізовано найпроблемніші ділянки у співробітництві Украӥни 3 іншими державами регіону. Узагальнено варіанти покращення регіонального політико-географічного положення України.

Ключові слова: регіональне політико-географічне положення, співробітництво, пріоритетність співпраці, "гарячі" точки, Україна, Центральна Європа, Польща, Литва, Балто-Чорноморський альянс.

Вступ. Постановка проблеми дослідження. XXI ст. розпочалося для України і українського народу низкою загроз і випробувань, центром зародження яких знову, як і багато разів до цього, виступає Москва, яка продовжує жити власними міфами про "спільну колиску", "тисячолітню спільну історію", "осередок православ'я та слов'янства", "Третій Рим", "месіанську роль", "Крим наш" тощо. Як неодноразово довела історія та світова наука, всі ці міфи спеціально створені на замовлення царів-генсеків-президентів місцевими псевдонауковцями для прикриття банального російського імперіалізму та шовінізму. У Росії не хочуть розуміти, що вибудувана на брехні та приниженні інших власна велич обов'язково призведе до катастрофічних наслідків для самих же росіян. І якщо провідні колонізатори минулого - Велика Британія, Франція, Іспанія, Португалія, США - ще у середині XX ст. зуміли не лише відмовитися від своїх колоній, а й вибачитися за свої злодіяння, то Російська колоніальна система продовжує існувати нині й порівняно незначні територіальні втрати 90-х рр. XX ст. не дають їй спокою. Саме у цьому контексті варто розглядати події в Молдові, Грузії, Україні.

Російська агресія щодо України звісно не залишилася поза увагою міжнародної спільноти та провідних ії агентів. Абсолютна більшість держав висловили свою солідарність з Україною, однак, як показали три роки гібридної війни, у глобалізованому світі економічні інтереси часто домінують над політичними цінностями. I в
США, і в Європейському Союзі все частіше лунають голоси про послаблення або зняття санкцій із Росії. Думаючи на перспективу, Україні вже нині варто визначити коло найважливіших союзників.

На нашу думку, окрім окремих держав ЄС, Канади i, за певних умов, США, найкращими союзниками у протистоянні із російським шовінізмом можуть стати окремі держави Центральної Європи, оскільки саме цей регіон, хоч і меншою мірою, ніж Україна, але зазнав на собі "месіанство" Росії. Насаджування комплексу меншовартості, депортації, мільйони людських життів та інші складові російської присутності $€$ найважливішим чинником у налагодженні тісної та взаємовигідної співпраці держав регіону. Саме окремі центральноєвропейські держави демонструють не лише підтримку України, а й готовність піти на ще більші економічні втрати заради зняття будь-яких загроз із боку Росії.

Аналіз останніх досліджень і публікацій. Політико-географічне положення (ПГП) України неодноразово ставало предметом дослідження українських та зарубіжних науковців (із останніх та найважливіших: М. Дністрянський [4], О. Шаблій [15], 3. Бжезінський [2], С. Лотоцький та С. Трохимчук [8], Д. Базів [1]), однак анексія Криму та російська агресія на сході держави внесли суттєві корективи в оцінку його вигідності, особливо на сусідському та регіональному рівнях. Виявилося, що окремі погляди на регіональне ПГП України, які були висловлені у першій половині $\mathrm{XX}$ ст. 
С. Рудницьким [10], В. Кубійовичем [6], Ю. Липою [7], є навіть більш актуальними, ніж погляди сучасників.

Мета статті полягає у тому, щоб з урахуванням подій 2014-2017 рр. висвітлити сучасне регіональне ПГП України, у тому числі згрупувавши країни регіону за пріоритетністю для нашої держави.

Виклад основного матеріалу. "Регіональне ПГП держави - це її ставлення до політичних даностей (держав, військово-політичних блоків, міжнародних організацій) у певному регіоні та стосовно "гарячих" точок планети" $[13$, с. 256]. Говорячи про регіональне політикогеографічне положення України, ми повинні наголосити на належності нашої держави саме до Центральної Європи, а не будь-якого іншого історико-географрічного регіону. Саме із центральноєвропейськими державами, як зазначалося раніше [14], Україна має найбільше спільних історичних та суспільно-географічних рис, які визначали її становище в минулому та визначають нині.

На сьогодні у складі регіону 20 держав, включно із Республікою Косово, яку Україна поки що не визнала офіційно. Візуально Україна займає південно-східні околиці Центральної Європи, проте завдяки своїй площі й відносно великій кількості сусідів має дуже високі показники центральності: індекс Бавелаша - 26,51; абсолютний індекс доступності - 39. За мірами центральності у регіоні вона поступається лише Угорщині (індекс Бавелаша - 27,95; абсолютний індекс доступності - 37). Шість із семи сухопутних сусідів України першого порядку та вісім із 18 другого є державами Центральної Європи.

Цікавим фактом, який ніяк не вписується в російський міф про "православно-слов'янську" цивілізацію 3 центром у Москві, $€$ те, що у Центральній Європі знаходиться 12 слов'янських держав (шість із них є членами ЄC та сім - НАТО) і у дев'яти державах провідним релігійним напрямом $€$ православ'я (три з них $є$ членами $€ С$ та чотири - НАТО; крім того, в обох організаціях присутня ще й православна Греція, а в ЄС - Кіпр). Абсолютна більшість центральноєвропейських держав або вже $\epsilon$, або заявляє про свої наміри стати членами ЄС та НАТО. Натомість у контрольованому Росією СНД присутні лише дві слов'янські (у т. ч. Білорусь $є$ складовою Центральної Європи) та чотири православні (у т. ч. Білорусь та Молдова) держави. Загалом лише три православні та дві слов'янські держави входять до ЄЕAC. Виходячи із чисельності держав (не говорячи вже про їх рівноправність), ЄС та НАТО є більш православними і слов'янськими, ніж СНД та ЄАЕС.

Держави Центральної Європи, зокрема ті, що є членами ЄС та НАТО, досягли набагато кращих результатів на шляху суспільно-економічного розвитку та благополуччя громадян, ніж будь-яка із країн $\mathrm{CHД}$ та $Є A E C$. Саме тому держави Центральної Європи $€$ хорошим орієнтиром для поступу України та втілення власних економічних і політичних стратегій.

3 усіма державами регіону, окрім Косово, Україна має дипломатичні відносини й обмін дипломатичними місіями. За роки незалежності з усіма державами напрацьована значна нормативно-правова база співробітництва на двох- та багатосторонній основі. На кінець 2017 р. майже всі держави, окрім Білорусі (прийнята в рамках СНД Угода про зону вільної торгівлі не працює) $\mathrm{i}$ Косово, мають договори з Україною про зону вільної торгівлі. Після введення безвізового режиму з ЄС усі центральноєвропейські держави стали доступними українцям для туристичних поїздок. Із абсолютною більшістю держав Україна має спільні стратегічні цілі: участь у ЄС, НАТО, регіональна безпека, дотримання прав і свобод громадян, їхнє вільне переміщення через кордони. Проте у співробітництві 3 кожною окремо взятою державою існують і певні особливості.

Беручи до уваги низку показників соціальноекономічного розвитку і військово-стратегічного значення країн світу, ступінь нинішньої взаємодії та підтримку України, ми визначили їхню пріоритетність для нашої держави. Центральноєвропейські держави між виділеними нами шістьма групами пріоритетності розподілилися таким чином:

- 1 група - Чехія;

- 2 група - Польща, Румунія, Угорщина, Естонія, Литва, Словаччина, Болгарія, Латвія;

- 3 група - Словенія, Хорватія, Македонія, Молдова, Чорногорія, Албанія; зазначимо, що за нашими розрахунками, у цю саму групу потрапила і Росія, показник пріоритетності співпраці з якою перебуває на рівні Молдови та Чорногорії;

- 4 група - Сербія, Білорусь, Боснія та Герцеговина.

Рівень пріоритетності Республіки Косово не визначався.

Єдиний бал, який зумовив належність Чехії до першої, а Польщі до другої групи пріоритетності - це відмінність у ступені економічної свободи. Чехія визнається міжнародними експертами "відносно вільною", а Польща, як і абсолютна більшість держав регіону, $є$ "помірно вільною". Для пріоритетності взаємодії загалом економічна свобода є важливим показником. Якщо ж говорити про суто політичну пріоритетність, то Чехія поряд $з$ іншими центральноєвропейськими державами, які є членами ЄС (окрім Чорногорії) і НАТО, опиниться у другій групі пріоритетності:

- 2 група - Литва, Естонія, Словенія, Польща, Чехія, Румунія, Угорщина, Болгарія, Латвія, Словаччина, Хорватія, Чорногорія;

- 3 група - Молдова, Македонія, Албанія;

- 4 група - Сербія, Боснія та Герцеговина;

- 5 група - Білорусь (у цій самій групі - Росія).

Польща не просто $є$ нашим найбільшим західним сусідом, а й справжнім "адвокатом" України в Європейському Союзі. Зрозуміло, що польські політики у першу чергу відстоюють власні національні інтереси, оскільки вони вже добре засвоїли формулу 3. Бжезінського: "Без незалежної України не може бути незалежної Польщі" [2]. Саме від обопільних дій Польщі та України суттєво залежить безпекова ситуація в регіоні, у т. ч. утілення проекту Балто-Чорноморського альянсу (Міжмор'я), який, навіть, лише за членства двох держав може стати вагомим європейським гравцем і гарантом стабільності у регіоні. У різні періоди інтерес до ідеї проявляли зо два десятки держав: Польща, Україна, Білорусь, Литва, Латвія, Естонія, Фінляндія, Молдова, Угорщина, Румунія, Чехія, Словаччина, Фінляндія, Швеція, Туреччина, Грузія, Азербайджан, Болгарія, Греція, екс-Югославія. В ідеалі до об'єднання мають входити всі країни між Балтійським, Чорним та Адріатичним морями [9]. Звісно, що у нинішніх умовах проросійськи налаштовані Білорусь, Сербія, Греція, Чехія та Угорщина і нейтральна Фінляндія навряд чи долучаться до об'єднання. Однак, його життєздатність значною мірою залежатиме від волі найбільших країн регіону; Польщі, України, Румунії. Причому, навіть утворення політичного "трикутника" дасть змогу "говорити на рівних" із провідними країнами Європи і світу. Значно посилиться стратегічна вага альянсу за умов входження до нього Туреччини, Швеції, Болгарії, Грузії, Хорватії. Багато спільних інтересів із цими країнами мають Латвія, Литва, Естонія.

Поляки і українці продовжують жити переважно у власному дискурсі. Окремі політики обох держав дуже однобоко використовують непрості події з минулого 3 метою отримання політичних дивідендів. Так, українці у 
минулому завдали полякам великої шкоди. Але дії українців матимуть дещо інше забарвлення, якщо врахувати два моменти. По-перше, жорсткі дії українців, наприклад, національно-визвольні змагання XVII ст. чи Волинь-1943, в основному були відповідями на не менш жорсткі кроки польських колонізаторів (утиски української мови і православ'я, насаджування польської адміністрації, пацифікація, масові етнічні зачистки Закерзоння, терор Армії Крайової; вже після Другої світової війни і без волі українців - узгоджена між Польщею та СРСР зачистка прикордонних територій Польщі від українців (операція "Вісла") та західних областей УРСР від поляків). Жорсткі дії українців були складовою антиколоніальної, національно-визвольної боротьби, аналогічної до боротьби американців проти британців, алжирців та в'єтнамців проти фрранцузів, анґольців проти португальців і якими б кривавими не були будь-які антиколоніальні війни, ніхто у Великій Британії, Франції чи Португалії не називає їх геноцидом і не змушує новоутворені країни до каяття і компенсацій. По-друге, так звані "східні креси" для українців $є$ такими самими поверненими землями, як для поляків Вроцлав, Щецин, ҐожувВелькопольські чи Ґданськ.

"Таким чином, сусідські відносини стали трагедією обох народів, бо хоча агресором була влада Першої та Другої Речі Посполитої, але розплачувався за агресію людськими жертвами польський народ. Після шести століть безперервної боротьби, якщо не фрізичної, то політичної, запанував нарешті спокій, коли поляків із України вигнали: але фатальна пам'ять про мертвих залишила в Польщі почуття антиукраїнської ненависті. I навіть більшої, ніж до німців, хоча українці ніколи польських земель не окупували, а боротьба між обома народами відбувалася тільки на українських землях і ніколи на етнічно польських" [11].

Поділи Польщі та поділи між Польщею і Московією / Російською імперією України; колонізація Німеччиною польських північно-західних земель і польська колонізація українських етнічних земель; польські домовленості з А. Гітлером та приєднання частини Судет i домовленості СРСР із Німеччиною про поділ Польщі; перенесення західних кордонів Польщі та України після Другої світової війни; найменування польських вулиць іменем Р. Дмовського та українських іменем С. Бандери повинні мати однаково об'єктивну оцінку. Перш ніж огульно засуджувати дії С. Петлюри або С. Бандери, які діяли відповідно до національних інтересів України, поляки мали б критично поставитися і до дій Ю. Пілсудського, який співпрацював і з С. Петлюрою, і 3 керівниками СРСР, і з А. Гітлером, тому що цього від нього вимагали національні інтереси Польщі. Варто наголошувати на тому, що і українці, і поляки тривалий час пліч-о-пліч жили на просторах від Кракова і Любліна до Києва і Дніпра цілком мирно в періоди, коли із власної волі або під впливом ззовні не намагалися в черговий раз перекроїти політичну карту. I навіть у найкривавіші періоди і з одного, і з іншого боку знаходилися тисячі звичайних людей, які боронили своїх сусідів іншої мови та віри. Наприклад, захищаючи Польщу від російсько-німецької агресії 1939 р., у польській армії змагалося 110 тис українців (майже кожен десятий воїн). Варто перестати мріяти про черговий переділ кордонів, і тоді тих, хто буде готовий піти на смерть заради спасіння сусіда, ставатиме все більше.

Ні українцям, ні полякам не варто автоматично відкидати всі неприємні питання спільних відносин, але вони не повинні стати перешкодою на шляху розбудови дійсно рівноправних добросусідських взаємин у майбутньому. Під історією потрібно підвести спільний зна- менник, визнавши спільну провинну в подіях, що відбулися і не вимагаючи один від одного сатиссракції. Минуле не можна забувати, але нехай про протиріччя говорять лише маргінали обох країн, а українське й польське суспільства і політикуми мають акцентувати увагу на співпраці та крок за кроком істиною вибивати ґрунт із під ніг радикалів. У добросусідських відносинах не має бути тиску. Ніколи не варто уподібнюватися Росії, від якої потерпали й потерпають і Україна, і Польща.

Історію варто пам'ятати, але у відносинах з демократичними країнами й рівноправними сусідами вона не повинна домінувати Варто, щоб у наших державах міфи не підміняли собою реальність, як це сталося в Росії. Хорошим прикладом для Польщі й України має бути повоєнне примирення Німеччини та Франції. Варто дослухатися до слів Посла Польщі в Україні Яна Пєкло: "Історія є історією, а майбутнє майбутнім. Я думаю, що й польський, і український уряди розуміють: у жодному разі нам не можна сваритися, ми обов'язково маємо порозумітися, адже наша справа $є$ спільною" [12]. Лише тоді "яґеллонське марення" про рівноправний стратегічний союз Польщі та України, а ще ширше - про Міжмор'я, стане дійсністю.

Наявність позитивного досвіду спільної державності часів Великого князівства Литовського та негативного досвіду російської колонізації перетворюють у важливого партнера України Литву. Якщо сучасні угорські, чеські чи словацькі політики не дуже хочуть пригадувати період примусового перебування у соцтаборі, то для литовських політиків і громадян російська окупація 1939-1991 рр. продовжує залишатися болючою темою. Литві дуже зрозумілими є необґрунтовані звинувачення Росією у недотриманні прав "русскоґоворящіх соотєчєствєнніков", "переписуванні історії", "фрашизмі"... Л. Донскіс зазначає: "Росіяни називають Україну фашистською, щоб приховати поширення фашизму й атмосфрери ненависті та ксенофобії в самій Росії" [5, с. 21]. Подібні чинники зближують на міжнародній арені позиції України і з іншими прибалтійськими державами.

Із групи сусідів другого порядку дуже важливою $є$ багатостороння співпраця також 3 Естонією, Латвією, Чехією, Хорватією.

Вагомою геополітичною передумовою взаємодії України із Чехією $є$ відсутність спільного кордону. Це добре вписується у геополітичні доктрини, згідно з якими дружити у першу чергу варто із сусідами сусідів. Та й минуле україно-чеських відносин порівняно із Польщею, Румунією, Угорщиною було менш проблематичним. Важливу роль у налагодженні взаємодії із Чехією може відіграти і українська діаспора: за підрахунками на сьогодні кожен 10 мешканець країни - українець [див. табл. 1]. Проте українській діаспорі нині не вистачає згуртованості, тому відносно малочисельна, але високоосвічена і добре згуртована українська політична діаспора початку XX ст. відігравала для популяризації України значно більшу роль.

Не дивлячись на низку суперечностей, із моменту проголошення Україною незалежності відносно позитивно розвивалися відносини з Румунією, Угорщиною та Словаччиною. Вони підтримали цілісність України і введення санкцій проти агресора. Однак, російські групи впливу залишаються тут доволі потужними. Шкода, що окремі європейські політики мають коротку пам'ять і забули, наприклад, як угорці або чехи у 50-60-х рр. XX ст. волали до світу про російську (радянську) агресію. Нині ж, коли Росія анексувала український Крим і воює на українському сході, В. Орбан і М. Земан не бачать жодних ознак російської присутності в Україні 
та співають промосковську пісню про "громадянську війну" та "київську хунту".

Черговим приводом для загострення відносин став Закон України "Про освіту", який викликав низку критики з боку Угорщини, Румунії, Болгарії, Молдови, Сербії. Угорщина навіть пригрозила блокувати всі питання, що стосуватимуться України в рамках ЄС. Президент Румунії відмінив свій візит до України. Частково їхнє занепокоєння викликане піклуванням про долю своїх діаспор в Україні. Більшою ж мірою це занепокоєння зініційоване російськими агентами (місцевими ультраправими, ультралівими і відверто популістськими силами) та проросійськими засобами інформації, які свідомо подають викривлену інформацію про суть даного закону. У відстоюванні власних позицій Україні варто наголошу- вати на відповідності Закону міжнародним нормам, прагненні завершити деколонізацію та адекватності захисту прав національних меншин усіма державами, а не лише Україною. Зазначимо, що окремі центральноєвропейські держави (Словаччина, Сербія, Хорватія, Польща) усупереч українській позиції продовжують виокремлювати русинів і лемків як окремі народи, всіляко заохочуючи такий поділ. При цьому від України ультимативно вимагають дотримання таких прав національних меншин, які самі активно ігнорували. Адже, навряд чи демократичними методами можна було б досягнути такої шаленої асиміляції українців [див. табл. 1]. Україні вже давно варто набагато активніше захищати права українців на всьому постсоціалістичному просторі.

Таблиця 1. Динаміка української діаспори в окремих державах Центральної Європи [складено на основі даних переписів]

\begin{tabular}{|c|c|c|c|}
\hline \multirow{2}{*}{ Держава } & \multicolumn{2}{|c|}{ Чисельність українців, тис. осіб } & Основні ареали сучасного проживання \\
\hline & попередньо & останні дані & 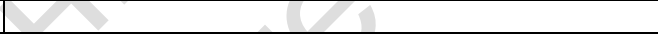 \\
\hline Білорусь & $\begin{array}{l}\text { бл. } 700 \text { (у Західній } \\
\text { Білорусі, польський } \\
\text { перепис, 1931); } \\
291 \text { (1989) }\end{array}$ & $158,7(2009)$ & Брестська та Гомельська області; Мінськ \\
\hline Болгарія & дані відсутні & $1,8(2011)$ & розпорошені \\
\hline $\begin{array}{l}\text { Боснія та } \\
\text { Герцеговина }\end{array}$ & $\begin{array}{l}4 \text { (із них } 133 \text { русини) } \\
\text { (1991) }\end{array}$ & дані відсутні & $\begin{array}{c}\text { Прнявор, Дервента, Баня-Лука, Девґятин, } \\
\text { Казарець, Стара Дуброва, Камениця, Босанскі Ґрад }\end{array}$ \\
\hline Латвія & $92,1(1989)$ & $45,7(2011)$ & Рига, Дауґавпілс \\
\hline Литва & $44,8(1989)$ & $16,4(2011)$ & Вільнюс, Каунас, Друскінінкай, Клайпеда \\
\hline Молдова & $600,4(1989)$ & $\begin{array}{c}\text { 442,4 (у т. ч. у Придністров'ї - 160) } \\
(2004)\end{array}$ & $\begin{array}{c}\text { Придністров'я; Кишинів, Бєльці; Окницький, } \\
\text { Бричанський, Ришканський райони }\end{array}$ \\
\hline Польща & $\begin{array}{c}3250(1931) \\
\text { бл. } 740 \\
\text { (середина } 40-x)\end{array}$ & $\begin{array}{c}58 \text { (із них українці - 48, лемки - } \\
10 \text { (2011) } \\
\text { (за оцінками із врахуванням заробіт- } \\
\text { чан до } 1,3 \text { млн) }\end{array}$ & $\begin{array}{c}\text { Західнопоморське, Поморське, Вармінсько- } \\
\text { Мазурське, Любуське, Великопольське воєводства; } \\
\text { південний схід; Варшава, Краків, Вроцлав }\end{array}$ \\
\hline Румунія & $68,3(1956)$ & $50,9(2011)$ & Мармарощина, Сучава, Банат, Добруджа \\
\hline Сербія & $\begin{array}{c}\text { 26,2 (із них 20,6 - русини, } \\
\text { 5,6 - українці) (1971) }\end{array}$ & $\begin{array}{c}19,1 \text { (із них 14,2 - русини, 4,9- } \\
\text { українці) (2011) } \\
\end{array}$ & $\begin{array}{c}\text { Воєводина (Руські Крстур, Нові-Сад, Бачка, } \\
\text { Срєм) }\end{array}$ \\
\hline Словаччина & $\begin{array}{c}383,4(1891) \\
90(1930)\end{array}$ & $\begin{array}{c}\text { 40,9 (із них 7,4 - українці); за мовою } \\
61,2 \text { (із них українська - 5,7) (2011) }\end{array}$ & Пряшівщина та східні райони \\
\hline Угорщина & дані відсутні & $6,2(2010)$ & розпорошені \\
\hline Хорватія & $10,0(1976)$ & $\begin{array}{c}4,3 \text { (із них 2,3 - русини, 2,0 - українці) } \\
\text { (2007) }\end{array}$ & $\begin{array}{c}\text { Петровці, Міклошевці, Вуковар, Осієк, Славонські } \\
\text { Брод, Каніжа, Сібінь, Липовляни, Раєво Село }\end{array}$ \\
\hline Чехія & $19,4(1950)$ & $\begin{array}{c}171,4 \text { (із них 117,8 - українців- } \\
\text { заробітчан (106,0 легально)) (2011) }\end{array}$ & Прага, Пльзень, Брно; Судети \\
\hline
\end{tabular}

Серед балканських країн варто виокремити Хорватію. Активний політичний діалог із цією країною розпочався після початку російської агресії проти України. Хорватія свого часу пережила подібні дії з боку Сербії (Югославії). Деокупація захоплених сербами територій, запровадження реформ, енергетична безпека, досвід вступу в НАТО та ЄС - лише частина тем, що цікавлять Україну. Важливими союзниками України в регіоні можуть бути Словенія і Чорногорія (особливо у контексті участі України в запобіганні державного перевороту, організованого російськими і сербськими спецслужбами).

Поряд із об'єктивним бажанням України мати дружні та взаємовигідні відносини з центральноєвропейськими державами, варто враховувати і дії Росії у регіоні. Звісно, що російський вплив на політичні партії та окремих діячів у державах Центральної Європи призводить до формування негативного іміджу нашої держави та суттєво погіршує стосунки з Україною, власне як і несе певні загрози для збереження цілісності ЄС і НАТО. Найчастіше Росія використовує власну таємну агентуру (у т. ч. так звані "консерви" - агентів, завербованих ще КДБ СРСР), фінансові вливання й корупційні схеми для впливу на політику держав регіону, однак інколи діє відкрито, нахабно порушуючи принципи міжнародного права: кібератаки на Естонію, відкрите втручання у ви- бори Президента Молдови, порушення повітряного простору Литви, спроба державного перевороту в Чорногорії тощо. Особливо відчутними $є$ російський вплив на політиків Білорусі, Сербії, Чехії, Угорщини, Молдови, Болгарії. Проте і у відносинах з цими державами Україні насамперед варто шукати точки дотику із минулого, акцентувати увагу на вигодах двосторонніх відносин нині й на перспективу та постійно доносити до їхніх громадян власні аргументи у протистоянні з Росією.

Важливим моментом, який зближує позиції України, центральноєвропейських держав та ЄС, $€$ висвітлення фактів підтримки Росією право- та ліворадикальних політиків, які всіляко пропагують євроскептичні погляди.

Загалом варто констатувати, що вплив України та рівень інформації про нашу державу в регіоні $€$ недостатнім. До покращення ситуації приведуть:

- присутність у різного роду регіональних організаціях та пропагування ідеї БЧА, тим паче, що створення останньої не суперечить інтересам НАТО, має певну підтримку в США та ЄС;

- активізація кроків щодо вступу в НАТО, розширення співробітництва у рамках ЄС (із перспективою вступу);

- активізація дипломатичної, економічної, культурно-освітньої діяльності; 
- пошук точок дотику у розвінчуванні радянськоросійських міфів та оперування реальними історичними фрактами; постійне розмежування понять "Русь" і "Росія", "русич" і "росіянин", "руський" і "російський" або "русскій";

- посилення інформаційної присутності (інформація в Інтернеті мовами країн регіону; обмін 3МІ).

Негативним аспектом регіонального ПГП України $є$ близькість до регіонів політичної напруги і окремих "гарячих точок" планети. Україна безпосередньо межує із самопроголошеною Придністровською Молдавською республікою. На відстані у 1,5 тис. км від українського кордону знаходяться багаторічні ареали нестабільності: Північний Кавказ, Абхазія, Південна Осетія, Нагірний Карабах, Ірак, Сирія, Ліван, Ізраїль, Турецька Республіка Північного Кіпру, Косово тощо. Кожен із цих конфліктів створює загрозу розширення ареалу нестабільності. Анексія Криму та російсько-терористична діяльність на сході України вже підтвердили такі побоювання. За оцінками Дж. Ф. Даніґена та О. Бея, у будьякий момент може вибухнути ситуація на Балканах, особливо в Боснії та Герцеговині, Косово, Македонії [3].

Україна $€$ активним учасником миротворчих операцій під егідою $\mathrm{OOH}$, то ж вправі розраховувати на відповідну допомогу світового співтовариства у відстоюванні власної територіальної цілісності. Ситуація в Європі може стабілізуватися лише тоді, коли Росія отримає чіткий і підкріплений практичними кроками сигнал, що Україна $є$ невід'ємною складовою євроатлантичної спільноти і марення В. Путіна, засновані на дуґінській геополітиці, та гроші "Газпрому" не похитнуть жодного європейського, як, власне, і українського, політика у відстоюванні європейських цінностей. Кроком до цього $є$ введення санкції стосовно Росії членами міжнародного співтовариства.

Висновки. Регіональне політико-географрічне положення України визначається її належністю до групи центральноєвропейських держав. Зарахування України до будь-якого іншого історико-географічного регіону $\epsilon$ неприпустимим і не відповідає ні її цивілізаційному, ні фрізико-географрічному місцезнаходженню. Крім того, Україна є причорноморською державою. Це забезпечує їй вихід у Світовий океан і можливість налагодження взаємовигідної співпраці з багатьма країнами світу.

Між державами, особливо географічно близькими, рідко існує повна довіра та взаєморозуміння, найчастіше вони вимагають дуже кропіткої й багаторічної праці, однак політики часто переймаються власними одномоментними рейтингами, а не напрацюваннями майбутнього.

У Центральній Європі Україна не має відкритих ворогів, але і справжніх друзів України в регіоні не так вже й багато: Литва, Естонія, Хорватія, Чорногорія. Польща $€$ важливим стратегічним партнером України, але часто акцентує увагу на суперечливих проблемах. Низка країн перебуває під сильним впливом російського політичного та економічного лобі. Новітні проросійські сили і залишені ще з радянських часів "консерви" усіма методами дестабілізують ситуацію в державах Центральної Європи, "ліплять" із України образ непередбачуваного партнера, ворога і недієздатної держави. Поки що вони у меншості й це на користь нашої держави, але за відсутності адекватної політики та активних дій вони можуть завоювати широку підтримку. Політики окремих країн залежно від політичної кон'юнктури у будь-який момент можуть задіяти антиукраїнські лозунги і перейти до вузьконаціональних, а не регіональних чи панєвропейських інтересів. Окремі центральноєвропейські держави - Словенія, Македонія, Албанія (одна із небагатьох країн поза межами ЄС, яка долучилася до санкцій), Боснія та Герцеговина - традиційно і абсолютно незаслужено лише спорадично потрапляють у фокус уваги українських дипломатів і політиків. Проте на даному історичному етапі всі держави регіону висловлюють підтримку цілісності України та виступають за розвиток взаємовигідних і різносторонніх відносин. Регіональна співпраця $€$ важливою для всіх країн, адже "крім потужних союзників добре мати й добрих сусідів" [9, с. 30]. У відносинах із державами регіону Україна має дотримуватися чіткої позиції та в жодному разі не шукати компромісу лише за рахунок власних національних інтересів.

Серед безпосередніх зовнішніх викликів національній безпеці України в регіоні варто згадати наявність неврегульованого конфллікту в придністровському регіоні Республіки Молдова; відсутність демаркації державного кордону України з Республікою Білорусь та Республікою Молдова; наявність неврегульованих проблемних питань з Угорщиною, Румунією, Польщею; безпекова ситуація на Балканах; підривна діяльність російського лобі та проросійських сил у регіоні.

Україна цивілізаційно, навіть не зважаючи на вікову російську колонізацію, завжди була і залишається складовою Європи і варто не зупинятися на шляху до повноцінної інтеграції в ЄС і НАТО, яка значно поліпшить регіональне політико-географрічне положення нашої держави.

\section{Список використаних джерел} 2000.

Базив Д. П. Геополитическая стратегия Украины / Д. П.Базив. -

2. Бжезінський 3. Велика шахівниця / Збіґнєв Бжезінський ; пер. 3 англ. Олена Фашовець. - Львів ; Івано-Франківськ, 2000.

3. Данниген Ф. Дж. Самые горячие точки XXI века. Как будут развиваться события / Джеймс Ф. Данниген, Остин Бэй / пер. с англ. А. Колина. - М., 2014.

4. Дністрянський М. С. Політична географія та геополітика України: навч. посіб. / М. С. Дністрянський. - Тернопіль, 2010.

5. Донскіс Леонідас. Прокляття шаблонної риторики / Леонідас Донскіс // Український тиждень. - 2014. - № 10(330).

6. Кубійович В. Географія України і сумежних країв / Володимир Кубійович. - Краків ; Львів, 1943

7. Липа Ю. Розподіл Росії / Юрій Липа. - Львів, 1995.

8. Лотоцький С. Україна в світовому геополітичному просторі: моногр. / С. Лотоцький, С. Трохимчук. - Львів, 2002.

9. Новікова К. Архітектори Міжмор'я / К. Новікова, В. Трубис // Український тиждень. - 2016. - № 36(460).

10. Рудницький С. Українська справа зі становища політичної географыї / Степан Рудницький. - Берлін, 1923.

11. Сивіцький M. Історія польсько-українських консрліктів / М. Сивіцький. - К., 2005. - Т. 1-3.

12. Сірук Микола. Посол Польщі Ян Рєкло: Ми розуміємо, що безпека України - це і наша безпека, а безпека Польщі - це й безпека України" [Електронний ресурс] / Микола Сірук. - Режим доступу: https://day.kyiv.ua/uk/article/den-planety/posol-polshchi-yan-pyeklo-myrozumiyemo-shcho-bezpeka-ukrayiny-ce-i-nasha.

13. Стафрійчук В.І. Політична географрія світу: навч. посіб. В. І. Стаффійчук. - Херсон, 2016

14. Стафрійчук В. Центральна Європа як історико-географрічний регіон / В. Стафійчук // Економічна і соціальна географрія. - 2002. - Вип. 53.

15. Шаблій Олег. Україна // Географрія: світи, регіони, концепти ; пер. з англ. - К., 2004.

References

1. Bazyv D. P. Heopolytycheskaya stratehyya Ukraynы / D. P. Bazyv. K., 2000.

2. Bzhezins'kyy Z Velyka shakhivnytsya / Zbignyev Bzhezins'kyy: [pereklad z anhl. Olena Fashovets'] - L'viv-Ivano-Frankivs'k, 2000.

3. Dannyhen F. Dzh. Sambe horyachye tochky XXI veka. Kak budut razvyvat'sya sobыtyya / Dzheyms F. Dannyhen, Ostyn Bэy [perevod s anhl. A. Kolyna]. - M., 2014

4. Dnistryans'kyy M. S. Politychna heohrafiya ta heopolityka Ukrayiny: Navch. posibnyk / M. S. Dnistryans'kyy. - Ternopil', 2010.

5. Donskis Leonidas. Proklyattya shablonnoyi rytoryky / Leonidas Donskis // Ukrayins'kyy tyzhden'. - 2014. - \#10(330).

6. Kubiyovych V. Heohrafiya Ukrayiny i sumezhnykh krayiv Volodymyr Kubiyovych. - Krakiv ; L'viv, 1943.

7. Lypa Yu. Rozpodil Rosiyi / Yuriy Lypa. - L'viv, 1995.

8. Lotots'kyy S., Trokhymchuk S. Ukrayina v svitovomu heopolitychnomu prostori: Monohrafiya / S. Lotots'kyy, S. Trokhymchuk. L'viv, 2002.

9. Novikova K., Trubys V. Arkhitektory Mizhmor"ya / K. Novikova, V. Trubys // Ukrayins'kyy tyzhden'. - 2016. - \#36(460).

10. Rudnyts'kyy S. Ukrayins'ka sprava zi stanovyshcha politychnoyi heohrafiyi / Stepan Rudnyts'kyy. - Berlin, 1923. 
11. Syvits'kyy M. Istoriya pol's'ko-ukrayins'kykh konfliktiv. T. 1-3 / M. Syvits'kyy. - K., 2005

12. Siruk Mykola. Posol Pol'shchi Yan Ryeklo: My rozumiyemo, shcho bezpeka Ukrayiny - tse i nasha bezpeka, a bezpeka Pol'shchi - tse y bezpeka Ukrayiny" / Mykola Siruk // Elektronnyy resurs - Rezhym dostupu: https://day.kyiv.ua/uk/article/den-planety/posol-polshchi-yan-pyeklo-myrozumiyemo-shcho-bezpeka-ukrayiny-ce-i-nasha
13. Stafiichuk V.I. Politychna heohrafiya svitu: Navch. posibnyk IV. I. Stafiichuk. - Kherson, 2016

14. Stafiichuk V. Tsentral'na Yevropa yak istoryko-heohrafichnyy rehion IV. Stafiichuk // Ekonomichna i sotsial'na heohrafiya. - 2002. - Vyp. 53.

15. Shabliy Oleh. Ukrayina // Heohrafiya: svity, rehiony, kontsepty. [Pereklad z anhl.] - K., 2004.

Надійшла до редколегії 06.10.17

В. Стафийчук, канд. геогр. наук, доц.

Киевский национальный университет имени Тараса Шевченко, Киев, Украина

\section{СОВРЕМЕННОЕ РЕГИОНАЛЬНОЕ ПОЛИТИКО-ГЕОГРАФИЧЕСКОЕ ПОЛОЖЕНИЕ УКРАИНЫ}

Рассмотрено современное региональное политико-ееографическое положение Украины как центральноевропейской страны. На основании бальной оценки центральноевропейские страны объединены в группы за приоритетностью сотрудничества для Украины. Раскрыты основные проблемы и направления дву- и многостороннего сотрудничества Украины с наиболее важными среди них, особенно Польшей, Литвой, Чехией, Румынией. Проанализировано наиболее проблематичные области сотрудничества Украины с другими странами региона. Подытожены варианты улучшения регионального политико-географического положения Украины.

Ключевые слова: региональное политико-ееографическое положение, сотрудничество, Украина, Центральная Европа, Польша, Литва, Балто-Черноморский альянс.

V. Stafiichuk, PhD Geography, Associate Professor

Taras Shevchenko National University of Kyiv, Kyiv,Ukraine

\section{CURRENT REGIONAL POLITICAL AND GEOGRAPHICAL SETTING OF UKRAINE}

The current regional political and geographical setting of Ukraine as a Central European state was suggested. Consideration of Ukraine in the context of any other historical and geographical region contradicts to scientific approaches and its real location. It was emphasized that the political and geographical setting of Ukraine in the beginning of the XX and the XXI centuries has a certain similarity, that makes the views of $S$. Rudnytsky, V. Kubiyovych, Y.Lypa still currently important. Ukraine, in terms of centrality, is the second country in the region after Hungary. Six out of seven land neighbors of Ukraine are Central European states, and other eight Central European countries are the second order neighbors. By using score-based estimation Central European states were grouped accordant to their priorities in cooperation concerning Ukraine. The states of the region were divided by the six groups of political cooperation priorities as follows: Group 2 - Lithuania, Estonia, Slovenia, Poland, Czech Republic, Romania, Hungary, Bulgaria, Latvia, Slovakia, Croatia, Montenegro; Group 3 - Moldova, Macedonia, Albania; Group 4 - Serbia, Bosnia and Herzegovina; Group 5 - Belarus. The main problems and directions of bilateral and multilateral cooperation of Ukraine with the most important of them (Poland, Lithuania, Czech Republic, Romania) were covered. The most problematic issues in cooperation of Ukraine with these and other states in the region (contradictory interpretation of historical events, the existence of myths, the influence of radical and populist political forces, support for the territorial integrity of Ukraine, sanctions against Russia, assimilation of national minorities, the use of national languages in the educational process), the ways of their overcoming and the ways of closer partnership establishing were analyzed. The dynamics of the number of Ukrainians in the states of Central Europe and the necessity for their protection are indicated. The current role of Russia and the ways of its influence on the policy of the states of Central Europe are pointed out and the main directions of neutralization of Russian negative influence are outlined. The importance for Ukraine of further steps towards the full integration into NATO, the EU, participation in existing regional organizations and further advancement of the idea of the Baltic-Black Sea Alliance is emphasized. The troubled areas in and close by Central Europe and their influence on the regional political and geographical setting of Ukraine are indicated. The options to improve the regional political and geographical setting of Ukraine were summarized.

Key words: regional political and geographical setting, cooperation, partnership, priority ranking in cooperation, troubled areas, Ukraine, Central Europe, Poland, Lithuania, Baltic-Black Sea Alliance.

\section{ПОШИРЕННЯ ПОЛІТИКИ ПОПУЛІЗМУ В ДЕМОКРАТИЧНИХ КРАЇНАХ ЗАХОДУ: СУСПІЛЬНО-ГЕОГРАФІЧНИЙ АНАЛІЗ ВИБОРІВ ПРЕЗИДЕНТА США 2016 РОКУ}

Роботу присвячено суспільно-географічному аналізу виборів президента США 2016 р. як індикативному прикладу поширення радикальних популістських ідеологій у західних демократіях. На основі аналізу електоральної ситуації у США у роботі стверджується, що причиною загальносвітового тренду посилення популістських політичних партій та рухів лежить криза взаємодії політичних еліт з їх базовим електоратом, що порушує ефективність демократичного представництва.

Ключові слова: електоральна географія, правий популізм, західні демократії, президентські вибори США.

Актуальність. Розвиток політичної карти світу, приблизно із середини XIX ст., характеризувався поступовим процесом поширення демократичних форм організації політичної влади у все ширших географічних межах. Ряд західних аналітиків вбачають у цьому процесі закономірність глобального політичного поступу, наголошуючи на безальтернативності демократичного шляху розвитку (Ф. Фукуяма [13], Л. Даймонд [10]). Водночас, провідний центр міжнародного моніторингу демократичних перетворень Freedome House, у своєму щорічному звіті зазначив, що 2016 р. став 11 роком поспіль загальносвітового скорочення політичних і громадянських свобод. При чому, якщо раніше погіршення ситуації із громадянськими й політичними правами переважно стосувалася країн 3 авторитарними режимами, то останнім часом погіршення ситуації спостерігається у так званих консолідованих демократіях - країнах, що завжди служили моделями ефективних інститутів державного управління. Електоральні події 2016 р. привернули увагу дослідників у цілій низці суспільних наук. На тлі загального посилення авторитаризму у світі в останні роки ці події дають підстави припускати загальносвітову тенденцію щодо сповільнення і навіть часткового згортання досягнень демократизації. Зміни політико-ідеологічних трендів як на глобальному рівні, так і в європейському регіоні, $\epsilon$ актуальним питанням для осмислення в Україні, адже зрушення у світовому політичному середовищі у бік націоналізму, авторитаризму i політичного реалізму можуть послабити зовнішній чинник сприяння демократичним перетворенням в Україні.

Головними загрозами у цьому плані $€$ посилення правої ідеології та популізму. Ознаками згортання демократичних свобод серед консолідованих демократій аналітики називають перемогу Дональда Трампа з його 